\title{
Oblicza prywatności - wyzwania i szanse świadomego uczestnictwa w świecie online
}

DOI: $10.47050 / 65591777.216-233$

Agnieszka Wrońska, Anna Rywczyńska

W artykule dokonano próby analizy terminu „prywatność" pod kątem znaczeniowo-definicyjnym i jako zjawiska społecznego w wymiarze technologii cyfrowej. Prezentowane badania potwierdzają rewolucyjny wzrost skali użytkowania sieci w ostatnich latach, zwłaszcza przez najmłodszych użytkowników. Ich coraz dłuższy czas aktywności w sieci, przekraczający często pięć godzin na dobę, coraz młodszy wiek samodzielnego korzystania z internetu oraz otwartość i aktywność w portalach społecznościowych stwarzają coraz więcej wyzwań w zakresie edukacji medialnej. Umiejętność świadomego uczestnictwa w świecie wirtualnym może zapobiegać potencjalnym zagrożeniom, chronić przed ryzykownymi zachowaniami, pomagać w bezpiecznym kształtowaniu swojej cyfrowej tożsamości. Na tle wyzwań związanych z prywatnością autorki prezentują również nowe zjawiska, między innymi technologie deepfakes czy „internet zabawek”.

\section{Słowa kluczowe:}

\section{zagrożenia w cyberprzestrzeni}

dziecko w internecie

internet

media społecznościowe

edukacja medialna

prywatność w sieci 


\section{Faces of privacy - challenges and chances of conscious participation in the online world}

DOI: $10.47050 / 65591777.216-233$

Agnieszka Wrońska, Anna Rywczyńska

The article attempts to analyze the term privacy, both in terms of meaning and definition, as well as the social phenomenon in the context of the digital technology. The presented research overview indicates a revolutionary increase in the use of the network in the recent years, especially in the context of the youngest internet users. Their ever-longer presence in the network, often exceeding five hours a day, the increasingly young age of independent use of the web as well as the openness and intense presence in the social networks create more and more challenges in the field of media education. The ability to consciously participate in a virtual world can counteract potential threats, protect against risky behaviors, and help in shaping the digital identity safely. In the context of challenges related to privacy, the authors also present new phenomena such as deepfakes technologies or the 'internet of toys'.

\section{Keywords:}

cyber dangers

child in the internet

internet

social media

media education

online privacy 


\section{Wprowadzenie}

Tematyka prywatności to ważne i coraz szerzej podejmowane zagadnienie we współczesnych naukach społecznych i prawnych. Z punktu widzenia zagrożeń związanych z rozwojem internetu szczególnie istotna wydaje się kwestia ochrony prywatności młodych osób korzystających z sieci. Internet cieszy się ogromnym powodzeniem - na szybki wzrost jego popularności składa się wiele czynników infrastrukturalnych, ekonomicznych i społecznych, związanych zarówno z łatwiejszym dostępem do sieci, jak i z korzyściami wynikającymi z jego używania. Rozwój technologii umożliwił łączenie się z siecią z dowolnego punktu, za pośrednictwem każdego urządzenia wyposażonego w odpowiednią technologię (tablet, smartfon, laptop, notebook). Atrakcyjność internetu wynika z możliwości szybkiego zdobywania aktualnych informacji i komunikacji z innymi oraz z dostępu do różnego rodzaju zasobów treściowych. Narzędzie to pozwala nie tylko korzystać z informacji udostępnionych w sieci, ale także tworzyć własne treści i publikować je. Społeczny wymiar użytkowania internetu wydaje się szczególnie ciekawy. Wraz z rozpowszechnieniem się tego narzędzia zniknęły granice państw i języków - użytkownicy z całego świata mogą bez przeszkód komunikować się ze sobą w dowolnym miejscu i czasie, a odległość przestała być barierą uniemożliwiającą interakcję. Zauważalny jest również wpływ internetu na wzory zachowań społeczeństw i poszczególnych grup społecznych (Wrońska, Lange 2016, s. 15). Wymiar zmian determinują zwyczaje, nawyki i sposoby użytkowania internetu zarówno przez ogół populacji, jak i przez młodych użytkowników, a to właśnie ta grupa postrzegana jako jedna z najbardziej aktywnych w sieci.

Przed erą internetu ochrona prywatności dotyczyła określonych sfer życia człowieka: opieki zdrowotnej, szkoły, pracy, ale także pamiętników czy informacji przekazywanych słownie. Zdobycie czyichś danych lub informacji o danej osobie mogło nastąpić tylko przez włamanie do archiwum albo uzyskanie materiałów od osoby trzeciej - zasięg jednak zarówno dostępu do danych, jak i potencjalnej ich dystrybucji był bardzo ograniczony. Rozwój technologii cyfrowej sprawił, że większość formalnych informacji o niemal każdym człowieku jest obecna w internecie, a sukces sieci społecznościowych odpowiada za masowe pojawienie się w obrazów, filmów i zapisków naszej codzienności, które nagle z prywatnych archiwów trafiają do setek, niekiedy nawet tysięcy odbiorców. Sieć pozwala prezentować swoje dokonania, lansować twórczość i osiągnięcia, nawiązywać relacje i przyjaźnie bez względu na dzielące nas odległości. 
Zgromadzenie jak największego grona „znajomych" w portalach społecznościowych daje szczególnie młodym ludziom poczucie satysfakcji i szczęścia oraz podnosi ich samoocenę. Z drugiej jednak strony publikując informacje na swój temat, często bez stosowania ustawień prywatności umożliwiających bezpieczniejsze zarządzanie profilami, wpuszczamy do swojego świata osoby, których intencje wobec nas lub działania mogą się okazać realnym zagrożeniem.

Same usługi sieciowe, serwisy i portale, wymagające podania wielu danych podczas logowania, nie zawsze gwarantują skuteczną ochronę. Prawie codziennie do mediów trafia informacja o kolejnym poważnym "wycieku" informacji (tak stało się po włamaniu na blisko pięćdziesiąt milionów kont na Facebooku' lub po przejęciu wielkich zbiorów danych osobowych z internetowych systemów randkowych, które służyły jako wielkie zasobniki big data). Dane użytkowników w internecie to również cyfrowe ślady, które zostawiamy po sobie sami lub robią to nasi bliscy i znajomi. Ślady, których istnienia możemy nie być świadomi, albo takie, z którymi niekoniecznie chcemy identyfikować się po kilku latach. $Z$ tego względu minimalizowanie ilości danych osobowych umieszczanych w sieci, ale także systematyczna weryfikacja naszej internetowej tożsamości, to elementy kluczowe do kontrolowania internetowego wizerunku. W wymiarze zagrożeń związanych z rozwojem internetu szczególnie ważna wydaje się kwestia ochrony prywatności młodych osób korzystających z sieci. Z badań wynika, że w młodym pokoleniu niemal wszyscy korzystają z internetu, nie zawsze jednak są w stanie uchronić się przed potencjalnymi zagrożeniami wirtualnego świata.

\section{Młodzi ludzie w sieci}

Skala obecności młodych ludzi w internecie zmienia się rewolucyjnie - w 2014 r. 74\% nastolatków deklarowało codzienną obecność w sieci, w 2016 r. odsetek ten wynosił już ponad 93\% (Nastolatki wobec Internetu... 2014; Kamieniecki i in. 2017, s. 9). 
Ilustracja 1. Korzystanie z internetu

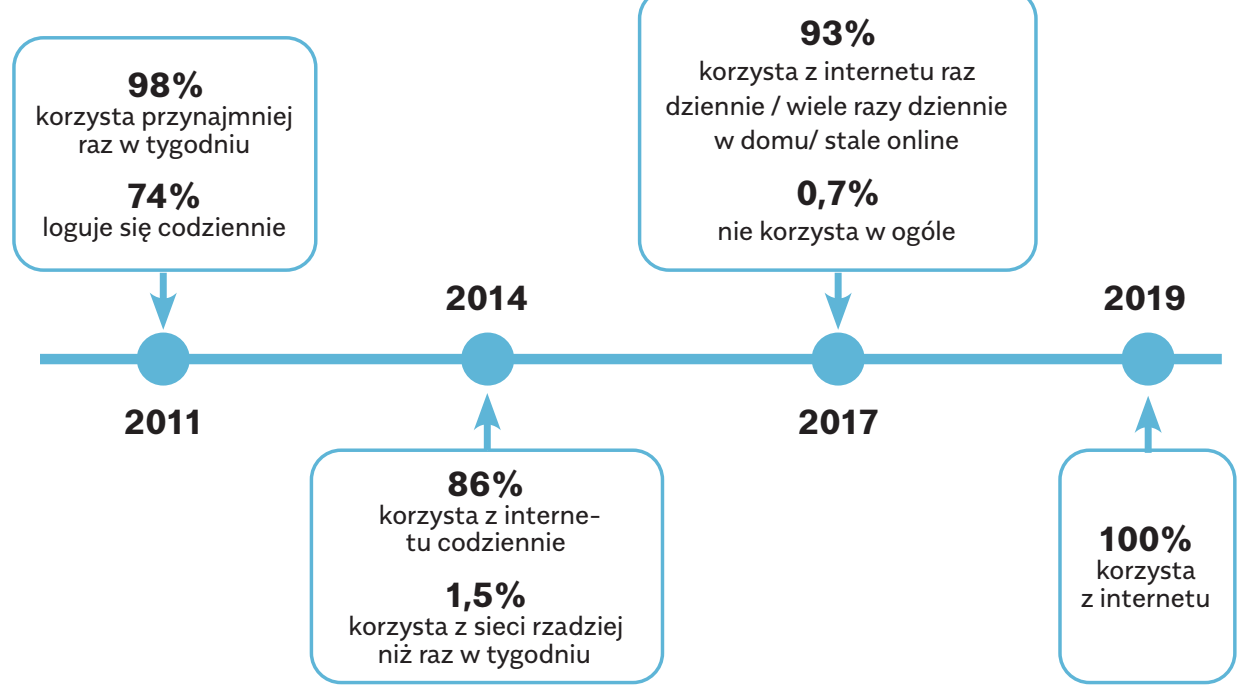

Źródło: Opracowanie własne na podstawie: L. Kirwil (2011); Nastolatki wobec Internetu...

(2014); Nastolatki $3.0(2017,2019)$.

Dzięki rozwojowi technologii mobilnej internet stał się towarzyszem nastolatka w szkole, w miejscach publicznych, w środkach komunikacji. Zdecydowana większość młodych ludzi deklaruje, że korzysta z internetu wiele razy dziennie lub przez cały czas: $w$ domu ( $80 \%)$, w szkole $(39,2 \%)$, u znajomych $(32,4 \%)$, w miejscach publicznych z dostępem do wi-fi $(29,7 \%)$ (Kamieniecki i in. 2017, s. 9). Podejmują oni wiele rozmaitych aktywności w sieci, w której są „od zawsze" i która stanowi nieodłączny element ich życia, a przestrzeń wirtualna towarzyszy im w ich aktywnościach poznawczych, rekreacyjnych i interakcyjnych (Wrońska, Lange 2016, s. 15). Można również zaobserwować systematyczne zmniejszanie się wieku, w jakim dzieci zaczynają samodzielnie korzystać z internetu - jeszcze kilka lat temu był to dziewiąty, dziesiąty rok życia dziecka (Kirwil 2011; Nastolatki wobec Internetu... 2014; Tanaś [red.] 2016), obecnie jest to siedem i mniej lat (UKE 2017; Wrońska, Lange i in. 2018, s. 13). Internet przyciąga młodych ludzi ze względu na łatwość użytkowania, multimedialność, interaktywność i hipertekstowość. Stanowi wsparcie w nauce szkolnej, źródło informacji i wiedzy, pomaga 
w realizacji pasji i zainteresowań, a coraz częściej staje się miejscem realizacji aktywności twórczej, kształtowania swojego wizerunku, wyrażania siebie oraz nawiązywania i budowania relacji społecznych. Internet to dla dzieci i młodzieży przede wszystkim sfera poznawania świata: 86,7\% za istotny uważa dostęp do przeglądarek internetowych, $80 \%$ - do najnowszych informacji, 57,4\% - do rozrywki, 86,4\% - do filmów, muzyki, a 71,2\% traktuje sieć jako narzędzie komunikacji (Kamieniecki i in. 2017, s. 46). Nieco rzadziej młodzi internauci używają internetu do aktywności służących autoprezentacji oraz podtrzymywania obecnych i pozyskiwania nowych kontaktów (43,5\% korzysta z możliwości poznania nowych znajomych, 42,6\% z dostępu do informacji o innych osobach). Niemal wszyscy młodzi użytkownicy internetu są obecni w mediach społecznościowych - 95\% nastolatków deklaruje, że ma profile w serwisach społecznościowych, a ich aktywność na tych forach koreluje z codziennością offline (Kamieniecki i in. 2017, s. 52-54).

Zdecydowana większość nastolatków wskazuje, że korzysta z sieci codziennie, a dzięki powszechnemu dostępowi do urządzeń mobilnych (przede wszystkim smartfonów) blisko połowa młodych użytkowników pozostaje online przez cały dzień.

„Internet umożliwił powstanie cyberprzestrzeni i licznych światów wirtualnych. Wkraczający w owe krainy nastolatek ma na nie realny wpływ. Może stać się kim chce, a nie tym, kim pragną uczynić go inni. Jest wolnym człowiekiem. Sam decyduje o typach podejmowanych działań w sieci, tworzy i poznaje, słucha i ogląda, jest biernym lub aktywnym internautą. Ma poczucie podmiotowości [...] to on kreuje własne życie w cyberprzestrzeni. Nie dotyczą go żadne nakazy i zakazy. W swym przekonaniu jest anonimowy i nie ponosi (ani ponosić nie będzie) żadnych konsekwencji za swe czyny. Skrzykuje się z kolegami podejmując akcje społeczne, nawiązuje indywidualne kontakty, szuka swej Julii lub Romea oraz rozumiejących go przyjaciół, zamieszcza komentarze, korzysta z komunikatorów i portali społecznościowych, dzieli się fotografiami, filmami oraz własnym doświadczeniem, gra i... coraz bardziej zamyka się w tak bardzo własnej, interaktywnej i wielowymiarowej, elektronicznej przestrzeni" (Tanaś 2016a, s. 8).

Poza niezaprzeczalnymi zaletami korzystanie z internetu niesie ze sobą także wiele realnych zagrożeń. Dotyczą one zarówno złośliwego oprogramowania, jak i kontaktu ze szkodliwymi treściami publikowanymi w sieci, ale są również wynikiem podejmowanych przez nastolat- 
ki zachowań ryzykownych czy niebezpiecznych relacji, które niosą ze sobą konsekwencje w różnych sferach życia - finansowej, psychicznej i społecznej. Niezwykle ważna jest także kwestia prywatności, ponieważ młodzi użytkownicy, często nieświadomi konsekwencji braku dbałości o swoją prywatność lub lekceważący skutki takich działań, są szczególnie narażeni na związane z tym reperkusje.

Portale społecznościowe służą nastolatkom przede wszystkim do autoprezentacji, komunikowania się i poznawania innych osób, a także do dzielenia się materiałami -zarówno własnymi (prywatne zdjęcia i filmy), jak i publikowanymi przez innych. Badania "Nastolatki 3.0" wskazują, że młodzi użytkownicy mediów społecznościowych udostępniają na swoich profilach coraz więcej informacji. Obok podstawowych danych, takich jak imię i nazwisko, nastolatki ujawniają dane, które pozwalają zidentyfikować właściciela konta. Młodzi ludzie na swoich profilach najczęściej umieszczają zdjęcia prezentujące ich rozmaite aktywności, czy dokumentujące podejmowane działania, a także informacje oraz opinie (llustracja 2).

Ilustracja 2. Materiały publikowane przez nastolatków na portalach społecznościowych

własne zdjęcia i filmy (niemal $80 \%$ osób)

informacje i komentarze dotyczące bieżącego dnia (54,7\%)

linki do filmów i zdjęć pochodzących z innych serwisów internetowych (53\%)

memy $(53,6 \%)$

zdjęcia innych osób $(43,5 \%)$

linki do artykułów z innych serwisów $(35,6 \%)$

Źródło: W. Kamieniecki i in. (2017). 
Jednym z ważniejszych wymiarów aktywności online jest stosunek do prywatności w cyberprzestrzeni. Mimo że coraz większy odsetek młodych ludzi ma świadomość konsekwencji, jakie niesie za sobą udostępniane w internecie prywatnych informacji i treści, to nadal duża grupa nie chroni swoich danych. W największym stopniu dotyczy to najmłodszych użytkowników sieci. Zdecydowana większość nastolatków stosuje różne procedury kontroli swojej cyfrowej „obecności” w przestrzeni internetowej (udostępnianie informacji tylko znajomym lub modyfikowanie możliwości dostępu zależnie od rodzaju prezentowanej informacji), ale mimo deklarowanej wiedzy dotyczącej ochrony młodzi ludzie udostępniają w sieci bardzo dużo informacji o sobie. Zarządzanie informacją $w$ internecie zmienia się wraz $z$ wiekiem nastolatków, co wynika ze wzrastających potrzeb i obaw młodego pokolenia. Większość respondentów deklaruje, że zdaje sobie sprawę z możliwych konsekwencji braku kontroli nad treściami umieszczonymi w internecie i podejmuje różne aktywności służące ochronie swoich danych oraz treści umieszczonych w przestrzeni wirtualnej $(57,6 \%$ twierdzi, że ogranicza dostęp, chroni swoją prywatność, 8,2\% dokonuje stosownych ustawień prywatności, boi się bowiem niewłaściwego wykorzystania swoich danych czy zdjęć). Co piąty $(21,9 \%)$ respondent twierdzi jednak, że nie dostrzega szczególnych zagrożeń z tym związanych, a tym samym nie widzi potrzeby ograniczania dostępności do swoich materiałów, a 5,2\% ankietowanych specjalnie nie filtruje informacji o sobie, ponieważ zależy im, aby ich autoprezentacja dotarła do jak największej liczby internautów. Brak znajomości procedur ograniczania dostępności danych w sieci w badanej populacji właściwie nie występuje, tylko niewielka część $(1,8 \%)$ respondentów wskazała, że nie potrafi zastosować takich procedur (Kamieniecki i in. 2017). 
Tabela 1. Rozkład procentowy odpowiedzi na pytanie:

„Wskaż, dlaczego wybierasz takie, a nie inne ustawienia profilowe?"

\begin{tabular}{l|c}
\multicolumn{1}{c}{ ODPOWIEDź } & ODSETEK \\
\hline ograniczam dostęp, bo chronię swoją prywatność & $57,6 \%$ \\
\hline $\begin{array}{l}\text { nie ustawiam prywatności, bo chcę być widoczny/widoczna dla jak największej liczby użyt- } \\
\text { kowników }\end{array}$ & $5,2 \%$ \\
\hline nie widzę potrzeby ograniczania dostępności & $21,9 \%$ \\
\hline nie ustawiam prywatności, bo nie potrafię tego zrobić & $1,8 \%$ \\
\hline ustawiam prywatność, bo boję się niewłaściwego wykorzystania moich danych, zdjęć & $8,2 \%$ \\
\hline inne powody & $1,9 \%$ \\
\hline nie korzystam z portali społecznościowych & $3,4 \%$ \\
\hline Ogółem & $100 \%$
\end{tabular}

Źródło: W. Kamieniecki i in. (2017).

\section{Wlasny obraz w sieci}

Współczesny świat oferuje wiele sposobów na tworzenie własnego wizerunku i swojej tożsamości, a tylko od nas zależy odpowiedź, kim jesteśmy i dokąd zmierzamy (Giddens 2004, s. 53). Możliwość zaistnienia na portalach społecznościowych i aktywnego uczestnictwa w kształtowaniu świata wirtualnego przez zamieszczanie własnych treści tekstowych i multimedialnych (na przykład na blogach, forach, w komentarzach i tweetach), przybiera różne formy i jest dla wielu osób bardzo kusząca. Internet ułatwia prezentację własnych dokonań i doświadczeń oraz wylansowanie swojej twórczości, pozwala także na nawiązywanie nowych relacji, ponieważ zamieszczone treści mogą oglądać i komentować internauci z całego świata. Jednocześnie niska wiedza użytkowników dotycząca zagadnień związanych z ochroną własnych danych i nieświadomość konsekwencji dzielenia się z innymi swoimi codziennymi aktywnościami powoduje, że coraz bardziej zaciera się granica między życiem prywatnym a "upublicznionym", otwartością a udostępnianiem zbyt dużej ilości informacji - często dochodzi wręcz do sytuacji, kiedy użytkownicy tracą kontrolę nad tym, ile i jakie informacje o nich są komunikowane innym. Mając na uwadze często nieuświadomiony ogrom danych, które funkcjonują w sieci na nasz temat, kluczowe wydaje się systematyczne sprawdzanie historii naszych internetowych aktywności, ale także danych, które mogły się pojawić w sieci bez naszego udziału. Gwałtownie rośnie popularność 
serwisów umożliwiających audyt internetowej tożsamości. Wpisując w ich wyszukiwarki adres e-mail lub imię i nazwisko, można prześledzić to, co pojawia się w internecie na nasz temat. Globalny zasięg sieci i zróżnicowane regulacje legislacyjne dotyczące ochrony prywatności w różnych krajach to czynniki, które sprawiają, że bardzo często nasze dane przekazywane są między różnymi systemami i portalami. Największą zmianę w zakresie systemowej ochrony danych osobowych wprowadziło rozporządzenie o ochronie danych osobowych (RODO) ${ }^{2}$ z 25 maja 2018 r., które obliguje firmy internetowe i portale do zwiększenia ochrony danych osobowych oraz nakłada obowiązek pilnego usunięcia danych osobowych i wszelkich danych kont na żądanie internauty zgłoszone do administratora danego serwisu.

Ochrona prywatności w sieci to coś, na co tylko po części mamy wpływ. Nawet dbałość o wizerunek w internecie oraz odpowiedni dobór publikowanych informacji mogą nas nie uchronić przed tym, że nasze zdjęcia czy filmy zostaną przedstawione w okolicznościach, na które nie wyraziliśmy zgody, albo wręcz zostaną przekształcone przy wykorzystaniu najnowszej technologii modyfikacji treści, czego skutkiem będą tak zwane deepfakes. Technologia ta umożliwia syntezę obrazu z wykorzystaniem sztucznej inteligencji i uczenia maszynowego - w ten sposób można łączyć istniejące obrazy i filmy z innymi obrazami źródłowymi. Rozwiązanie to jest wykorzystywane między innymi w branży filmowej, pozwala bowiem na dokonanie wielkich oszczędności przy produkcji filmów, na dogrywanie scen bez udziału aktorów lub unowocześnianie starszych filmów. Niestety, rozwiązanie to kojarzy się głównie z przemysłem pornograficznym, w którym służy do produkcji fałszywych filmów z udziałem na przykład osób publicznych. Deepfakes bywają też wykorzystywane do tworzenia fałszywych informacji i mogą być narzędziem nieetycznej walki politycznej (znane są przykłady manipulowania w ten sposób wypowiedzi osób ze świata polityki).

\section{Prywatność - definicje}

Pojęcie prywatności pojawia się w publikacjach wielokrotnie, ale mimo kilku prób, które podjęto w celu pełnego opisania tego terminu, trudno jest stworzyć uniwersalną definicję, między innymi ze względu na 
pojemność tego zjawiska i ciągłą zmianę elementów należących do sfery prywatnej jednostki. Większość definicji jedynie podkreśla pewne aspekty prywatności. Oczywiście granice między "prywatnym” a "publicznym" różnią się w zależności od danej epoki i społeczeństwa, co spowoduje ciągłą zmianę obszarów, które ludzie uważają za prywatne. Prywatność wiąże się również z konkretnymi uwarunkowaniami, co oznacza, że dzielenie się tymi samymi informacjami w różnych sytuacjach może być uważane za prywatne lub nie.

Również indywidualne podejścia osób, w tym użytkowników internetu, do rozumienia prywatności i sfery publicznej zdają się coraz bardziej zacierać w wymiarze wzajemnego przenikania się i oddziaływania światów online i offline. Badania nad zarządzaniem prywatnością online rozwijają się równolegle w ramach wielu dyscyplin, w tym nauk informatycznych i technicznych ( $w$ których pojęcie to rozpatruje się między innymi z punktu widzenia szeroko rozumianego bezpieczeństwa teleinformatycznego, ochrony danych w przestrzeni cyfrowej i systemów teleinformatycznych przed włamaniami, kradzieżą czy nieuprawnionym wykorzystaniem danych) (Klimek 2015, s. 96), a także nauk prawnych (między innymi z punktu widzenia ochrony i udostępniania informacji online oraz prawnych implikacji związanych z prawem do prywatności) lub nauk społecznych (tutaj nacisk położony jest zarówno na e-umiejętności, postawy, jak i przyczyny oraz konsekwencje oraz zależności związane z przemianami w obszarze prywatności i wpływem internetu na użytkowników).

Prywatność często rozpatrywana jest jako zagwarantowane prawo przysługujące każdej jednostce. O prawie tym pierwsi zaczęli pisać pod koniec XIX w. Louis D. Brandeis i Samuel D. Warren, określając je jako the right to be alone - uprawnienie do samotności, wyłączności i odrębności tajemnicy (Pryciak 2010), możliwość „bycia zostawionym samemu sobie (Gajda 2008; Siuda 2015, s. 39), czyli prawo do zapewnienia sobie sfery prywatności wolnej od ingerencji innych osób, szczególnie podmiotów władzy (Breardsley 1971 [za: Braciak 2004, s. 38]), rozumianego jako możliwość decydowania o tym, jak wiele informacji o sobie chcemy ujawnić. Wspomniani badacze swoim artykułem otworzyli dyskurs, który doprowadził do tego, że prawo do prywatności stało się powszechnie znane, ewoluowało i stało się podstawowym prawem człowieka. Joseph Kohler określił prywatność jako swobodę rozporządzania informacjami na swój temat (Kohler 1907 [za: Braciak 2002]). 
Współcześnie pojęcie to nabrało szerszego znaczenia. Zdaniem Beate Roessler, prywatność oznacza „prawo do bycia autorem własnej biografii” (Roessler 2010 [za: Młynarska-Sobaczewska 2013, s. 35]), rozumiana jest już zatem nie tylko jako prawo do odosobnienia czy zachowania sekretu, ale także do decydowania o swoim losie, cielesności, życiu osobistym i rodzinnym oraz kształtowania swoich relacji z otoczeniem i własnej historii w określony swobodnie przez siebie sposób (tamże). Pozwala to na wyróżnienie trzech istotnych wymiarów: prawa do decydowania o swojej cielesności (prywatność ciała, prywatność fizyczna), prywatności informacyjnej, polegającej na decydowaniu o udostępnianych na swój temat informacji, prywatności osobistej (lokalnej), związanej z określaniem swoich zachowań i relacji rodzinnych, a także relacji ze społecznością. Tym samym konieczność zapewnienia prywatności z punktu widzenia nowych technologii może być utożsamiana w dużej mierze z prywatnością informacyjną, a nie tylko innymi rodzajami prywatności, na przykład ekonomiczną, gwarantowaną przedsiębiorcom (Siuda 2015, s. 39).

Encyklopedyczne i słownikowe definicje prywatności (z łac. privatus - oddzielony) ${ }^{3}$ określają ją jako zdolność jednostki lub grupy osób do kontrolowania swoich danych oraz osobistych zwyczajów i zachowań nieujawnionych publicznie. W najszerszym ujęciu prywatność jest utożsamiana z autonomią, niezależnością jednostki - jest to możliwość samodzielnego decydowania o własnym życiu, czyli wolność wyboru drogi życiowej bez jakiejkolwiek ingerencji zewnętrznej. Można ją także rozpatrywać z punktu widzenia możliwości jednostki lub grupy do rozpowszechniania informacji o sobie wyłącznie wśród wybranych osób. Różne ujęcia sprawiają, że trudno jest o jedną, pełną i jednoznaczną definicję prywatności.

Możliwe jest wyróżnienie trzech podstawowych metod traktowania prywatności: relacyjnej (iteracyjnej), dotyczącej kontroli kontaktów społecznych, informacyjnej, związanej z zasobem i charakterem przeczyjąś osobistą własność", "niepodlegający państwu ani żadnym instytucjom publicznym”, „dotyczący czyichś spraw osobistych i rodzinnych”. Mały słownik języka polskiego określa, że jest to termin „dotyczący kogoś osobiście, stanowiący czyjąś osobistą własność, nie związany z żadną instytucją, urzędem”, "niepaństwowy, nieurzędowy, domowy”. W encyklopediach, leksykonach, słownikach można odnaleźć różne definicje pojęcia „prywatność", na przykład w odniesieniu do prywatnego lub osobistego charakteru czegoś, w odniesieniu do czegoś, co nie jest przeznaczone do publicznego rozgłoszenia, w ujęciu własnościowym (jako dobro nie dla każdego dostępne lub dostępne w ograniczonym zakresie). 
kazywanych informacji, i przestrzennej (fizycznej), dotyczącej fizycznej dostępności do danej osoby (Dopierała 2013).

W aspekcie prawnym prywatność została przedstawiana między innymi przez Andrzeja Kopffa (1972) jako dobro osobiste: „w postaci życia prywatnego jest to wszystko, co ze względu na uzasadnione odosobnienie się jednostki od ogółu służy jej do rozwoju fizycznej lub psychicznej osobowości oraz zachowania osiągniętej pozycji społecznej".

W literaturze przedmiotu można znaleźć różne podejścia koncepcyjne i sposoby opisywania pojęcia prywatność. Daniel J. Solove opracował sześć kategorii dla tych definicji, zgodnie z którymi prywatność to prawo do wolności, ograniczony dostęp do siebie, tajemnica, kontrola danych osobowych, osobowość i intymność (Solove 2002). Podobnie jak w naukach prawnych, także w obszarze nauk społecznych pojawiły się próby podania definicji zjawiska prywatności. Stephen T. Margulis porządkuje te propozycje, wyróżniając trzy grupy znaczeniowe: potoczne (common), empiryczne (empirical) i prawne (legal) (Margulis 1977 [za: Jędruszczak 2005]). Zebrane i przytaczane przez Stephena T. Margulisa definicje prywatności opracowane przez różnych autorów wyraźnie wskazują wieloaspektowość prywatności w naukach behawioralnych i społecznych. Pojęcie to było określane między innymi jako "selektywna kontrola dostępu do siebie lub grupy, do której należy jednostka" (Altman 1977). Wskazywano, że "prywatność odnosi się do negacji potencjalnych relacji opartych na władzy między osobą lub grupą a innymi" (Kelvin 1993), a także twierdzono, że "w psychologicznym sensie służy maksymalizacji wolności wyboru, pozwala jednostce czuć się wolną, zachowywać się w określony sposób lub poszerzać zakres opcji w odniesieniu do tychże zachowań poprzez niwelowanie pewnych rodzajów społecznych ograniczeń" (Proshansky, Ittelson, Rivlin).

\section{Wygoda czy bezpieczeństwo danych}

Interesujące są wyniki globalnego badania EMC Privacy Index z 2014 r., prezentującego sposób postrzegania praw i możliwości w zakresie prywatności online przez konsumentów na całym świecie, a także ich gotowości do rezygnacji z korzyści i wygód oferowanych przez usługi sieciowe, aby chronić swoją prywatność. Badaniem objęto 15 tysięcy osób z piętnastu krajów, a wyniki wskazały trzy paradoksy związane z prywatnością i poufnością: "Chcemy mieć wszystko bez kompromisów", „Brak działania” oraz „Udostępnianie w sieciach społecznościo- 
wych". Użytkownicy twierdzą, że chcą korzystać z zalet technologii, ale jednocześnie nie zamierzają rezygnować z tego powodu z prywatności. Prawie wszyscy badani $(91 \%)$ cenią sobie zalety technologii cyfrowych z powodu łatwiejszego dostępu do informacji i wiedzy, ale tylko $27 \%$ respondentów wyraża gotowość do zrezygnowania z części prywatności na rzecz uzyskania większego komfortu korzystania z serwisów online. Mimo że zagrożenia dotyczące prywatności dotykają bezpośrednio wielu konsumentów, większość użytkowników przyznaje, że nie podejmuje właściwie żadnych działań w celu ochrony swoich danych - $62 \%$ nie zmienia regularnie haseł, cztery na dziesięć osób nie konfigurują ustawień prywatności w sieciach społecznościowych, a 39\% badanych przyznaje, że nie chroni swoich przenośnych urządzeń hasłem. Konsumenci są skłonni uważać, że jest to raczej obowiązkiem podmiotów przetwarzających ich informacje, na przykład instytucji rządowych i przedsiębiorstw. Z jednej strony większość użytkowników portali społecznościowych (84\%) nie chce, aby ktokolwiek wiedział coś o nich albo o ich zwyczajach, dopóki sami nie zechcą udostępnić tych informacji, jednocześnie jednak osoby te przyznają, że swobodnie udostępniają duże ilości danych osobowych - mimo braku zaufania do podmiotów mających chronić te informacje.

Raport z badania EMC Privacy Index potwierdza, że użytkownicy zachowują się różnie w zależności od aktywności, które podejmują w sieci. Biorąc pod uwagę role, jakich się podejmują (na przykład obywatel, pacjent, pracownik czy konsument), należy stwierdzić, że ich postawa wobec kwestii prywatności jest zróżnicowana, na przykład większa jest chęć rezygnacji z prywatności w wymiarze obywatelskim, ale w sieciach społecznościowych użytkownicy byli najmniej skłonni zrezygnować z prywatności w zamian za lepszą obsługę. Umieszczone w raporcie wnioski dotyczą trzech grup: konsumentów, przedsiębiorców i dostawców technologii. Zdaniem autorów, widać konieczność podniesienia wiedzy na temat kwestii prywatności oraz podejmowania indywidualnych działań na rzecz jej ochrony wśród konsumentów. W wypadku przedsiębiorców istotna jest ich zdolność do wykazania, że stosują najskuteczniejsze i najbardziej praktyczne metody ochrony prywatności klientów, zadaniem dostawców technologii jest zaś zwiększenia poziomu prywatności w oferowanych rozwiązaniach, lecz bez negatywnych skutków dla komfortu użytkowania, wydajności lub zakresu możliwości. 
Badania dotyczące prywatności polskich internatów zostały przeprowadzone w 2013 r. i w latach 2016-2017 przez Związek Pracodawców Branży Internetowej IAB Polska ${ }^{4}$. Wyniku wskazują między innymi, że Polacy coraz lepiej radzą sobie w kwestii prywatności i coraz częściej stosują różnego rodzaju zabezpieczenia, które mają ją chronić. Internet jest postrzegany przez jego użytkowników jako przestrzeń publiczna (poza prywatnymi stronami WWW pozostałe serwisy internetowe uznawane są za publiczne albo częściowo publiczne). Rośnie poziom świadomości i wiedzy na temat prywatności. Tylko $4 \%$ badanych użytkowników sieci zadeklarowało, że nie korzysta z żadnych form ochrony prywatności. Najczęściej stosowane zabezpieczenia dotyczą ochrony przed wirusami, w porównaniu jednak z wcześniejszym badaniem można mówić o upowszechnianiu się form zabezpieczeń i sposobów ochrony prywatności. Wyniki raportu z 2016 r. pokazują, że w porównaniu z wcześniejszym badaniem z 2013 r. zwiększył się również odsetek osób, które dbają o swój wizerunek w sieci - na przykład nie umieszczają w sieci prywatnych zdjęć i posługują się pseudonimami (z 49\% w roku 2013 do 62\% w 2016 r.). Internauci wykazują większą wiedzę na temat prywatności i zainteresowanie tą tematyką, jednocześnie deklarują, że w niedostatecznym stopniu są poinformowani w tym zakresie. Interesująca jest deklaracja użytkowników na temat udostępnianie danych osobowych - z jednej strony podkreślają oni niechęć do podawania swoich danych w sieci, z drugiej zdecydowana większość potwierdza, że świadomie zamieszcza takie materiały $w$ sieci.

Wielu internautów ma świadomość zasad funkcjonowania środowiska cyfrowego i dostrzega korzyści płynące z personalizacji treści. Wyniki badania "Prywatność w sieci", podobnie jak cytowanego wcześniej EMC Privacy Index, pokazują dylematy związane z prywatnością. W tym wypadku dotyczą one różnic między deklarowaną chęcią zachowania prywatności a chęcią skorzystania z automatycznego dopasowania treści do potrzeb odbiorców. Z jednej strony zdecydowana większość badanych (79\% badanych) twierdzi, że przeszkadza im profilowanie behawioralne dokonywane przez serwisy internetowe, z drugiej zaś akceptuje treści stron internetowych i reklam dopasowane do ich preferencji na podstawie profilu behawioralnego (IAB 2017, s. 14). 


\section{Dzieci online - odpowiedzialność dorosłych}

Według wyników najnowszych badań dotyczących obecności w sieci najmłodszych internautów w Polsce (Korzystanie z urządzeń mobilnych... 2015) $64 \%$ dzieci w wieku od sześciu miesięcy do sześciu i pół roku korzysta z urządzeń mobilnych ( $25 \%$ z nich robi to codziennie). W grupie dzieci rocznych i dwuletnich aż $43 \%$ korzysta z tego typu urządzeń, a wśród sześciolatków - 84\%. Obecność najmłodszych osób w sieci rozpoczyna się często z chwilą opublikowania przez rodziców pierwszych zdjęć z USG, jeszcze przez ich narodzinami. To rodzice decydują o publikowaniu wizerunku dzieci od samych narodzin, często bezwiednie narażając je później na konsekwencje w przyszłości (na przykład na drwiny ze strony szkolnych kolegów). Zjawisko ośmieszania dzieci zdjęciami zrobionymi na przykład podczas pierwszych posiłków albo intencjonalne ośmieszanie dzieci $w$ ramach kary lub żartu doczekało się nawet osobnego terminu - troll parenting. $Z$ tego powodu coraz więcej mówi się $\mathrm{w}$ dyskursie publicznym o potrzebie edukacji dorosłych w zakresie dbania o prywatność swoich dzieci. Kluczowa jest także wiedza rodziców i nauczycieli w sprawie prywatności w sieci, aby móc wspierać młodych ludzi, kiedy już zaczną sami wkraczać w świat mediów społecznościowych. Dzieci często proszą rodziców o pomoc lub zgodę w zakładaniu swoich pierwszych profili w sieci - dorośli muszą wówczas znać wiek, od którego taka aktywność jest możliwa. Trzynaście lat to minimum obowiązujące w państwach członkowskich Unii Europejskiej zgodnie z rozporządzeniem RODO, niekiedy granica wieku wzrasta do szesnastu lat w zależności od krajowych regulacji. Pomocna może być tutaj znajomość najbardziej popularnych portali społecznościowych i oferowanych przez nie ustawień prywatności.

\section{Internet zabawek}

Rozwijającym się zjawiskiem związanym z kwestią prywatności dzieci jest technologia internetu rzeczy (Internet of Things, loT). Urządzenia oparte na infrastrukturze internetu i technologii mobilnych podatne są na zagrożenia wynikające z cyberprzestępczości, czyli na możliwe włamania w celu pozyskania danych użytkowników zapisanych w urządzeniach i stworzenia na tej podstawie fałszywych tożsamości, ale niosą także ze sobą wyzwania dotyczące zapisywania interakcji dziecka z urządzeniem. Mowa tutaj o internecie zabawek, czyli interaktywnych zabawkach podłączonych do sieci, które zapisują „rozmowy” prowadzone z dzieckiem 
i za pośrednictwem odpowiednych aplikacji udostępniają je rodzicom. Jak pokazują badania przeprowadzone w ramach projektu "Internet zabawek - wsparcie dla rozwoju dziecka czy zagrożenie" (Rywczyńska, Jaroszewski 2018), większość dzieci nie zdaje sobie sprawy z tego, że jest nagrywana i że komunikacja z zabawką może być bardzo łatwo udostępniona na przykład w portalach społecznościowych.

Internet rzeczy w wymiarze młodych ludzi to także tak zwana technologia ubieralna - często stosowana w celu zwiększenia bezpieczeństwa, przyzwyczajająca jednak dzieci do stałego monitoringu i kontroli, co może nie być bez wpływu na procesy rozwojowe młodych ludzi. W 2016 r. Family Online Safety Institute ${ }^{5}$ opublikował dokument Kids and the Connected Home: Privacy in the Age of Connected Dolls, Talking Dinosaurs, and Battling Robots, w którym wstępnie badany jest świat inteligentnych zabawek pod kątem bezpieczeństwa i podstaw zastosowania praw ujętych w COPPA (Children's Online Privacy Protection Act z 1998 r.) ${ }^{6}$ w odniesieniu do producentów zabawek i dostawców implementowanej w nich technologii.

Według czasopisma "Forbes"7 do 2025 r., zdaniem ekspertów, ponad $70 \%$ gospodarstw domowych na świecie będzie wyposażonych w urządzenia typu smart. Celem wspomnianego projektu dotyczącego internetu zabawek (Rywczyńska, Jaroszewski 2018) było sprawdzenie skali rozpowszechnienia technologii internetu rzeczy w Polsce - obecności inteligentnych zabawek i wiedzy o nich. W 2017 r. zrealizowano w tym celu badania ilościowe i jakościowe. Badanie ilościowe przeprowadzono na panelu Ariadna na ogólnopolskiej próbie polskich internautów (1051 osób) w wieku osiemnastu i więcej lat, w badaniach jakościowych posłużono się zaś metodą wywiadu pogłębionego. Rozmowy odbywały się w miejscach zamieszkania respondentów lub w miejscach ich czasowego pobytu. Przeprowadzono dwadzieścia cztery wywiady z rodzinami zróżnicowanymi według miejsca zamieszkania, wykształcenia, liczby dzieci i liczby opiekunów w rodzinie (oboje rodzice, samotny rodzic). Badania ilościowe musiały być przeprowadzone dwukrotnie, ponieważ pierwsza ankieta wykazała duży problem ze zdefiniowaniem urządzeń należących 
do internetu rzeczy. Często z urządzeniami typu smart mylono na przykład inteligentne pralki czy zmywarki, mające większą liczbę funkcji niż standardowe urządzenia. Najbardziej rozpowszechnionym urządzeniem typu smart w Polsce okazał się smart TV, którego użytkowanie zadeklarowała prawie połowa ankietowanych. Na kolejnych miejscach znajdują się kamery, systemy alarmowe i kino domowe. Interaktywne zabawki dla dzieci ma obecnie około $4 \%$ respondentów. Wywiady z rodzinami potwierdziły, że bardzo często osoby użytkujące urządzenie smart nie mają świadomości, co to oznacza.

Celem badania było także sprawdzenie, jak jest postrzegany rozwój rynku zabawek inteligentnych. Najbardziej pozytywnie nastawieni do tych technologii są mieszkańcy dużych miast - 10\% z nich udzieliło takiej odpowiedzi na pytanie: „Jak oceniasz fakt, że coraz więcej zabawek ma możliwość podłączenia do internetu?". Procentowo przeważało podejście neutralne i pozytywne, chociaż prawie 30\% badanych wyraziło duże obawy. Najczęściej rodzice zwracali uwagę na problematykę ochrony prywatności dziecka, obawiali się, że zabawka może dostarczać dziecku fałszywych emocji i że dziecko może być narażone na niebezpieczne kontakty. Osoby nastawione pozytywnie do zabawek smart mają nadzieję, że wpłyną one korzystnie na rozwój dziecka, zwłaszcza w wymiarze edukacyjnym. Kupując zabawkę dla dzieci, ponad $60 \%$ osób kieruje się bezpieczeństwem zabawki, nie wiadomo jednak, czy przekłada się to na kwestie związane z bezpieczeństwem internetowym, ponieważ nadal temat zagrożeń online jest rzadko obecny w polskich domach. Ponad 15\% rodziców nie prowadzi rozmów o tej kwestii, a 38,5\% rzadko ją podejmuje.

Prywatność w sieci wydaje się więc problemem niezwykle złożonym i niejednoznacznym. Decydując o obecności technologii cyfrowej w naszym życiu i korzystaniu z oferowanych przez nią udogodnień, musimy na co dzień podejmować wybory między wygodą a anonimowością, bezpieczeństwem dzieci a prawem młodych ludzi do indywidualnych, prywatnych przestrzeni, w które dorośli nie powinni ingerować. Kluczowe znaczenie ma rozwój edukacji medialnej, interdyscyplinarna praca nad budowaniem cyfrowego obywatelstwa - świadomości efektywnego korzystania z sieci, oraz dbałość, aby dzieci na początku swojej cyfrowej drogi mogły liczyć na mądre wsparcie dorosłych, odpowiedzialne podejście biznesu i rozwijające na każdym etapie edukacji wsparcie szkoły. 